results of the present study indicate that this mechanism of entry could also operate in the pathogenesis of Hib meningitis.

\section{References}

1. Moxon ER. Haemophilus infiuenzae. In: Mandell GL, Douglas RG, Bennett JE, eds. Principles and practice of infectious diseases. 3rd ed. New York: Churchill Livingstone, 1990:1722-9.

2. Moxon ER, Smith AL, Averill DR, Smith DH. Haemophilus influenzae meningitis in infant rats after intranasal inoculation. J Infect Dis 1974;129:154-62.

3. Moxon ER, Winkelstein JA. Interaction of Haemophilus influenzae with complement. In: Cabello FC, Pruzzo C, eds. Bacteria, complement and the phagocytic cell. NATO ASI series, Vol 24. Berlin: SpringerVerlag, 1988:177-86.

4. Noel GJ, Mosser DM, Edelson PJ. Role of complement in murine macrophage binding of Haemophilus influenzae type b. J Clin Invest 1990;85:208-18.

5. Weller PF, Smith AL, Smith DH, Anderson P. Role of immunity in the clearance of bacteremia due to Haemophilus influenzae. J Infect Dis 1978;138:427-36.

6. Moxon ER, Goldthorn JF, Schwartz AD. Haemophilus influenzae b infection in rats: effect of splenectomy on bioodstream and meningeal invasion after intravenous and intranasal inoculations. Infect Immun 1980;27:872-5.
7. Fothergill LD, Chandler CA, Dingle JH. The survival of virulent $H$. influenzae in phagocytes. J Immunol 1937;32:335-9.

8. Williams AE. Relationship between intracellular survival in macrophages and pathogenicity of Streptococcus suis type 2 isolates. Microb Pathog 1990;8:189-96.

9. Zwahlen A, Rubin LG, Moxon ER. Contribution of lipopolysaccharide to pathogenicity of Haemophilus influenzae: comparative virulence of genetically-related strains in rats. Microb Pathog 1986;1:465-73.

10. Kroll JS, Moxon ER. Capsulation and gene copy number at the cap locus of Haemophilus influenzae type b. J Bacteriol 1988;170:859-64.

11. Weiser J, Williams AE, Moxon ER. Phase-variable lipopolysaccharide structures enhance the invasive capacity of Haemophilus influenzae. Infect Immun 1990;58:3455-7.

12. Virji M, Weiser JN, Moxon ER. Antigenic similarities in lipopolysaccharides of Haemophilus and Neisseria and expression of digalactose structure also present on human cells. Microb Pathog (in press).

13. Kimura A, Hansen EJ. Antigenic and phenotypic variations of Haemophilus influenzae type b lipopolysaccharide and their relationship to virulence. Infect Immun 1986;51:69-79.

14. Williams AE, Blakemore WF. Monocyte-mediated entry of pathogens into the central nervous system. Neuropathol Appl Neurobiol 1990; 16:377-92.

15. Williams AE, Blakemore WF. Pathogenesis of meningitis caused by Streptococcus suis type 2. J Infect Dis 1990;162:474-81.

\title{
Resistance of Staphylococcus aureus Recovered from Infected Foreign Body In Vivo to Killing by Antimicrobials
}

\author{
Christian Chuard, Jean-Christophe Lucet,* \\ Peter Rohner, Mathias Herrmann, \\ Raymond Auckenthaler, Francis A. Waldvogel, \\ and Daniel P. Lew
}

Division of Infectious Diseases, University Hospital, Geneva, Switzerland

\begin{abstract}
Because persistence of infections associated with prosthetic material despite the use of appropriate antibiotics is a major clinical problem, the antimicrobial susceptibility of bacteria responsible for a chronic subcutaneous tissue cage infection in rat was investigated ex vivo. Three to 6 weeks after the initiation of infection, suspensions of two strains of Staphylococcus aureus recovered from the foreign body surface and surrounding fluid were exposed to either oxacillin, vancomycin, fleroxacin, gentamicin, or rifampin. The MBCs of these bacteria were markedly elevated, in most cases 128 to $>256$ times higher than the MBC of batch culture $S$. aureus in either logarithmic or stationary phase. Kinetic studies showed the bacteria did not grow when incubated for $2 \mathrm{~h}$ in Mueller-Hinton broth, possibly reflecting dormancy. Their killing was slow and incomplete by all antibiotics at $>8$ times their MIC. These data provide direct evidence of a decreased susceptibility of $S$. aureus to the killing effect of antimicrobials during chronic foreign body infections in vivo.
\end{abstract}

Received 4 June 1990; revised 4 February 1991.

Financial support: Swiss National Research Foundation (grant 3.829-0.87; fellowship 32-27222.89 to C.C.).

Reprints or correspondence: Dr. C. Chuard, Division of Infectious Diseases, Geneva University Hospital, CH-1211 Geneva 4, Switzerland.

* Present address: Intensive Care Unit, Bichat-Claude Bernard Hospital, Paris.

The Journal of Infectious Diseases 1991;163:1369-1373

(c) 1991 by The University of Chicago. All rights reserved.

0022-1899/91/6306-0033\$01.00
Infection is a major complication of implanted devices. Patients frequently do not respond to high doses of antimicrobial agents even if administered for prolonged periods, and foreign bodies usually must be removed to achieve cure. It is known that susceptibility to antibiotics may be profoundly affected by growth of microorganisms near biomaterials. Thus vancomycin, tested in a system mimicking infection of a peritoneal dialysis catheter, was unable to decrease the viability 
of a population of biofilm-enclosed Staphylococcus epidermidis [1]. Similarly, a significant survival of $S$. epidermidis adherent on steel was shown when the bacteria were exposed to a concentration of tobramycin 20-200 times higher than the MBC that had been measured for microorganisms in solution [2]. Others have reported similar results with Pseudomonas aeruginosa [3]. However, these in vitro models are characterized by an artificial environment in which bacteria grow for a short time in the absence of host factors under selected, not necessarily physiologic, conditions.

Here we used an experimental model of chronic subcutaneous tissue cage infection in rats [4] to explore the susceptibility of suspensions of Staphylococcus aureus recovered from the foreign body surface and surrounding fluid to the killing effect of various antistaphylococcal agents.

\section{Materials and Methods}

Bacterial strains and antimicrobial agents. The selected $S$. aureus strains 120 and MRGR3 were bloodstream clinical isolates from patients with intravenous catheter infections. Both were penicillinresistant, and MRGR3 was methicillin- and gentamicin-resistant. Standard reference preparations of all antibiotics were obtained from their respective manufacturers.

Animal model. Polytetrafluoroethylene multiperforated tissue cages (length, $32 \mathrm{~mm}$; diameter, $10 \mathrm{~mm}$ ) containing three polymethylmethacrylate coverslips $(7 \times 7 \mathrm{~mm})$ were implanted subcutaneously into the flank of Wistar rats. At 3-6 weeks after implantation, the fluid that had accumulated in the cages was inoculated with $1 \times 10^{5}$ to $1 \times 10^{6} \mathrm{cfu}$ of $S$. aureus $\mathrm{I} 20$ or MRGR3. Two weeks later, a sustained and stable infection $>1 \times 10^{5} \mathrm{cfu} / \mathrm{ml}$ of tissue cage fluid (mean, $1 \times 10^{7}$ to $1 \times 10^{8} \mathrm{cfu} / \mathrm{ml}$ ) was obtained in $>90 \%$ of cages [4].

Isolation of bacteria from tissue cage fluid and coverslips for susceptibility testing. Three to 6 weeks after infection, $0.1 \mathrm{ml}$ of tissue cage fluid was collected. It was centrifuged and the pellet was resuspended in PBS (GIBCO, Paisley, UK) with 0.1\% Triton X-100 (Merck, Darmstadt, FRG) for 5 min to disrupt host cells. After washing, bacteria were sonicated for $1 \mathrm{~min}$ at $60 \mathrm{~W}$ (model 2200; Brandson Ultrasoncis, Branbury, CT) to avoid clumping and then further diluted appropriately. In control experiments, the procedure was harmless for bacteria regarding their ability to multiply and their susceptibility to antibiotics. Clumping, monitored by microscopy, was very low.

Bacteria directly adherent to coverslips were also studied. Coverslips were rinsed three times in PBS by gentle agitation, then exposed to bovine trypsin (Serva, New York) 6 units/ml in PBS for $20 \mathrm{~min}$, and sonicated for $1 \mathrm{~min}$ at $60 \mathrm{~W}$; this method was shown microscopically to efficiently detach surface-bound $S$. aureus. Detached bacteria were washed and declumped. Controls proved this procedure did not affect microorganisms. The number of adherent bacteria recovered from three coverslips was 5-10 times less than that recovered from $0.1 \mathrm{ml}$ of simultaneously collected tissue cage fluid; therefore not all susceptibility tests applied to tissue cage fluid bacteria were possible with coverslip bacteria as the final inocula in the latter were sometimes too low.
Determination of $M B C$ and MIC by broth macrodilution. The broth macrodilution method recommended by the National Committee for Clinical Laboratory Standards [5] was strictly applied to determine the MIC and MBC (>99.9\% killing) of oxacillin, vancomycin, fleroxacin, gentamicin, and rifampin for S. aureus 120 and vancomycin, fleroxacin, and rifampin for $S$. aureus MRGR3. Tissue cage fluid bacteria were compared with logarithmic- $(3 \mathrm{~h})$ and stationary-phase (18-20 h) cultures grown in Mueller-Hinton broth (MHB; Difco, Detroit), designated in vitro bacteria. The final inoculum was $4 \times 10^{5}$ to $2 \times 10^{6} \mathrm{cfu} / \mathrm{ml}$ for both ex vivo and in vitro microorganisms. Carryover problems were solved at up to $256 \mu \mathrm{g} / \mathrm{ml}$ with oxacillin, fleroxacin, and gentamicin and at $2.56 \mu \mathrm{g} / \mathrm{ml}$ for rifampin. Coverslip-adherent bacteria could not be studied by this method.

For $S$. aureus MRGR3, the MIC and MBC of vancomycin were also measured after incubation for $20 \mathrm{~h}$ of batch culture stationaryphase bacteria in fibronectin ( $25 \mu \mathrm{g} / \mathrm{ml})$.

Determination of MIC and MBC by agar dilution. MICs and MBCs were determined entirely on solid media using a $\beta$-lactamase neutralization procedure for oxacillin on $S$. aureus $\mathrm{I} 20$ and a membrane transfer technique for vancomycin on $S$. aureus MRGR3.

In the $\beta$-lactamase neutralization procedure $[6,7]$, the inoculum is plated on oxacillin-containing Mueller-Hinton agar (MHA; Difco), a thin agar overlay is placed on the bacteria, the oxacillin is inactivated with a penicillinase solution (penase concentrate; Difco) after determination of the MIC at $24 \mathrm{~h}$, and the MBC is read after $48 \mathrm{~h}$ of further incubation. Penase concentrate $(1 \mathrm{ml})$ was found to inactivate $128 \mu \mathrm{g} / \mathrm{ml}$ oxacillin in $20 \mathrm{ml}$ of MHA. The inoculum was $0.1 \mathrm{ml}$ of a solution containing $2 \times 10^{5}$ to $4 \times 10^{5} \mathrm{cfu} / \mathrm{ml}$.

The membrane transfer technique was derived from similar procedures previously reported $[8,9]$. An inoculum $(50 \mu \mathrm{l})$ of $6 \times 10^{4}$ to $1 \times 10^{6} \mathrm{cfu} / \mathrm{ml}$ was plated on $4.7-\mathrm{cm}$-diameter, $0.45-\mu \mathrm{m}$ poresize cellulose filters (Millipore, Bedford, MA) lying on MHA plates containing vancomycin. After $24 \mathrm{~h}$ of incubation, the MIC was read; filters were subsequently transferred three times for $60 \mathrm{~min}$ onto MHA plates without antibiotic to eliminate vancomycin and finally incubated on MHA for $48 \mathrm{~h}$ for MBC determination. Vancomycin concentrations $\leqslant 256 \mu \mathrm{g} / \mathrm{ml}$ could be reliably washed away with this method.

Parts of colonies originating from bacteria that had survived an exposure to $256 \mu \mathrm{g} / \mathrm{ml}$ vancomycin were removed from membranes when the MBC was read. They were used in a suspension of $5 \times$ $10^{5} \mathrm{cfu} / \mathrm{ml}$, which was immediately plated on membranes and retested for $\mathrm{MBC}$.

Killing and growth kinetic studies. Bacterial kinetics were studied by growth and time-kill curves. Experiments were done in constantly agitated glass tubes containing $10 \mathrm{ml}$ of MHB. Samples were plated on MHA with a spiral plater (Spiral System, Cincinnati) and plates were read after $48 \mathrm{~h}$ incubation. Oxacillin, vancomycin, fleroxacin, and gentamicin were tested at 8 times their MIC; for rifampin, the concentration was 200 times the MIC to approximate the tissue levels measured during treatment in humans. The limit for detection of viable bacteria was $1.3 \log _{10} \mathrm{cfu} / \mathrm{ml}$ for the first four antibiotics and $2.3 \log _{10} \mathrm{cfu} / \mathrm{ml}$ for rifampin (solution diluted to avoid carryover). All plates without visible growth were considered to be at the detection limit.

Tissue cage fluid and in vitro bacteria were exposed to each antimicrobial agent (inoculum, $1 \times 10^{5}$ to $3 \times 10^{5} \mathrm{cfu} / \mathrm{ml}$ for $S$. 
aureus 120 and $1 \times 10^{6}$ to $3 \times 10^{6} \mathrm{cfu} / \mathrm{ml}$ for $S$. aureus MRGR3). Susceptibility of coverslip bacteria was assessed with oxacillin for $S$. aureus I20 and vancomycin for $S$. aureus MRGR3 (inoculum, $2 \times 10^{4}$ to $5 \times 10^{4} \mathrm{cfu} / \mathrm{ml}$ ).

Tissue cage fluid bacteria were also studied after they had been preincubated in $\mathrm{MHB}$ at $37^{\circ} \mathrm{C}$ for $4 \mathrm{~h}$ before exposure to antibiotics (S. aureus 120 with oxacillin and $S$. aureus MRGR3 with vancomycin).

Finally, a stationary-phase batch culture of $S$. aureus MRGR3 that was grown in broth containing fibronectin $(25 \mu \mathrm{g} / \mathrm{ml})$ for $20 \mathrm{~h}$ was tested with vancomycin.

Statistics. For time-kill curves, the Wilcoxon test for paired rankable scores (two-tailed) was used to compare at each time point the differences in mean count decreases between the three conditions tested for all antibiotics on both strains.

\section{Results}

MICs. No significant difference between MICs against in vitro (logarithmic- and stationary-phase) and ex vivo (tissue cage fluid and coverslips) bacteria was observed. Broth macrodilution and agar dilution methods yielded comparable results (table 1 ).

$M B C s$. For in vitro bacteria, the MBC-to-MIC ratio was 1-2:1 for all antibiotics tested except rifampin, which was not bactericidal against logarithmic- and stationary-phase $S$. aureus $\mathrm{I} 20$ and stationary-phase $S$. aureus MRGR3. Except for rifampin with $S$. aureus MRGR3, there was perfect con- cordance between the MBCs for exponential cultures and 18 to 20-h cultures.

The difference between in vitro bacteria and bacteria associated with the foreign body was striking, with a MBC-toMIC ratio $>128-256: 1$ in all conditions for the latter. Similar results were obtained for bacteria recovered from tissue cage fluid and coverslips.

The agar dilution method, which is not prone to artifactual results (falsely elevated $\mathrm{MBC}$ ) occasionally linked to the initial broth incubation phase of classic procedures, confirmed the results obtained with the broth macrodilution method (table 1).

Daughter cells originating from tissue cage fluid bacteria that survived exposure to a high concentration of antibiotic had the same MBC values as in vitro bacteria.

Preincubation of stationary-phase batch culture bacteria in fibronectin did not change their $\mathrm{MBC}$.

Kinetic studies. With bacteria in logarithmic phase, a decrease of viable counts of more than $3 \log _{10}$ (mean, $4.22 ; \mathrm{SD}$, 0.61 ; range, 3.37-5.03) after $24 \mathrm{~h}$, that is, bactericidal activity, was observed in all cases except for rifampin on $S$. aureus I20 (mean, 1.68). This decrease is underestimated since the detection level was reached in most cases. The $99.9 \%$ killing level was usually seen $8 \mathrm{~h}$ after antibiotic exposure. Control populations grown without antimicrobial agents showed a mean increase of $1.38 \pm 0.22 \log _{10}$ within the first $2 \mathrm{~h}$ of incubation.

Table 1. MIC and MBC ( $\mu \mathrm{g} / \mathrm{ml})$ of antimicrobial agents studied against Staphylococcus aureus strains I20 and MRGR3.

\begin{tabular}{|c|c|c|c|c|c|c|c|}
\hline & \multicolumn{3}{|c|}{ MIC } & \multicolumn{4}{|c|}{$\mathrm{MBC}$} \\
\hline & \multirow{3}{*}{$\begin{array}{l}\text { In vitro, } \\
\text { logarithmic/ } \\
\text { stationary }{ }^{\dagger}\end{array}$} & \multicolumn{2}{|c|}{ Ex vivo } & \multirow{2}{*}{\multicolumn{2}{|c|}{ In vitro }} & \multicolumn{2}{|c|}{ Ex vivo } \\
\hline & & & & & & & \\
\hline & & cage fluid & Coverslips & Logarithmic & Stationary & cage fluid & Coverslip \\
\hline \multicolumn{8}{|c|}{ S. aureus $\mathbf{1 2 0}$} \\
\hline \multicolumn{8}{|c|}{ Broth macrodilution } \\
\hline Oxacillin & 0.6 & 0.3 & ND & 0.8 & 0.7 & $>256$ & ND \\
\hline Vancomycin & 1 & 1 & ND & 1.5 & 1 & $>256$ & ND \\
\hline Fleroxacin & 0.9 & 0.9 & ND & 1 & 1.2 & $>256$ & ND \\
\hline Gentamicin & 1.4 & 1 & ND & 1.5 & 1.3 & $\geqslant 256$ & ND \\
\hline Rifampin & 0.02 & 0.01 & ND & $>2.56$ & $>2.56$ & $>2.56$ & ND \\
\hline \multicolumn{8}{|l|}{ Agar dilution } \\
\hline Oxacillin & 0.25 & 0.25 & 0.5 & 0.75 & 0.75 & $>128$ & $>128$ \\
\hline \multicolumn{8}{|c|}{ S. aureus MRGR3 } \\
\hline \multicolumn{8}{|c|}{ Broth macrodilution } \\
\hline Vancomycin & 0.9 & 1.4 & ND & 2 & 1.9 & $>256$ & ND \\
\hline Fleroxacin & 0.7 & 1.1 & ND & 1.1 & 1 & 256 & ND \\
\hline Rifampin & 0.01 & 0.01 & ND & 0.02 & $>2.56$ & $>2.56$ & ND \\
\hline \multicolumn{8}{|l|}{ Agar dilution } \\
\hline Vancomycin & 1.1 & 1.6 & 1.6 & 1.5 & 1.5 & $>200$ & $>200$ \\
\hline
\end{tabular}

NOTE. MICs and MBCs were determined by classic broth macrodilution and by $\beta$-lactamase inhibition or a membrane transfer agar dilution technique. Results are mean of $\geqslant 3$ determinations. ND $=$ not done.

$\dagger$ Identical results were obtained with in vitro cultures in logarithmic and stationary phases.

$\ddagger$ Suspensions of bacteria obtained from foreign body surface (coverslips) and surrounding fluid were directly tested with antimicrobial. 
The killing was slightly but significantly $(P=.028)$ less for stationary-phase bacteria but exceeded a $3 \log _{10}$ decrease in inoculum (mean, $3.90 \pm 0.44$; range, 3.32-4.54) after 24 $\mathrm{h}$ with all antibiotics but rifampin (mean, 1.76). Growth curves did not differ from logarithmic-phase bacteria control curves.

The decrease in viability of tissue cage fluid bacteria was significantly $(P=.028)$ slower than that of in vitro bacteria, whether tested in logarithmic or in stationary phase; rifampin, for which there was tolerance in vitro, was an exception. None of the antimicrobial agents, on either $S$. aureus I 20 or MRGR3, led to a $3 \log _{10}$ decrease in initial inoculum after $24 \mathrm{~h}$ of incubation (mean, $1.91 \pm 0.80$; range, 0.17 for rifampin on S. aureus I20 to 2.48 for gentamicin). In the absence of antibiotics, bacteria associated with the foreign body also behaved differently from in vitro microorganisms, since there was a 2-h delay for initiation of population growth (figure 1).

Bacteria directly detached from coverslips were studied with oxacillin for $S$. aureus $\mathrm{I} 20$ and vancomycin for $S$. aureus MRGR3. There was a strict parallelism between curves of tissue cage fluid and coverslip bacteria, whether or not exposed to antibiotics (with oxacillin, decrease from $5.31 \pm 0.22$ to
$2.90 \pm 0.36 \log _{10} \mathrm{cfu} / \mathrm{ml}$ after $24 \mathrm{~h}$ [difference, 2.41 ] for cage fluid and from $4.72 \pm 0.90$ to $2.19 \pm 0.27 \log _{10} \mathrm{cfu} / \mathrm{ml}$ [difference, 2.53] for coverslips).

When tissue cage fluid bacteria were preincubated in MHB for $4 \mathrm{~h}$ before they were tested, their kill curves and growth kinetics were comparable to those of batch culture bacteria.

Stationary-phase batch culture bacteria grown in broth containing fibronectin did not show a significant alteration of killing and growth patterns.

\section{Discussion}

This study found a markedly decreased susceptibility of $S$. aureus associated with foreign body infection in vivo to the killing effect of antibiotics when compared with batch culture bacteria of the same strain grown under conventional conditions. MBCs determined by the classical broth macrodilution method, which has been criticized [10], were confirmed by an agar dilution technique and by kinetic studies.

Resistance of microorganisms to the killing action of bactericidal antimicrobial agents due to their physiologic condi-
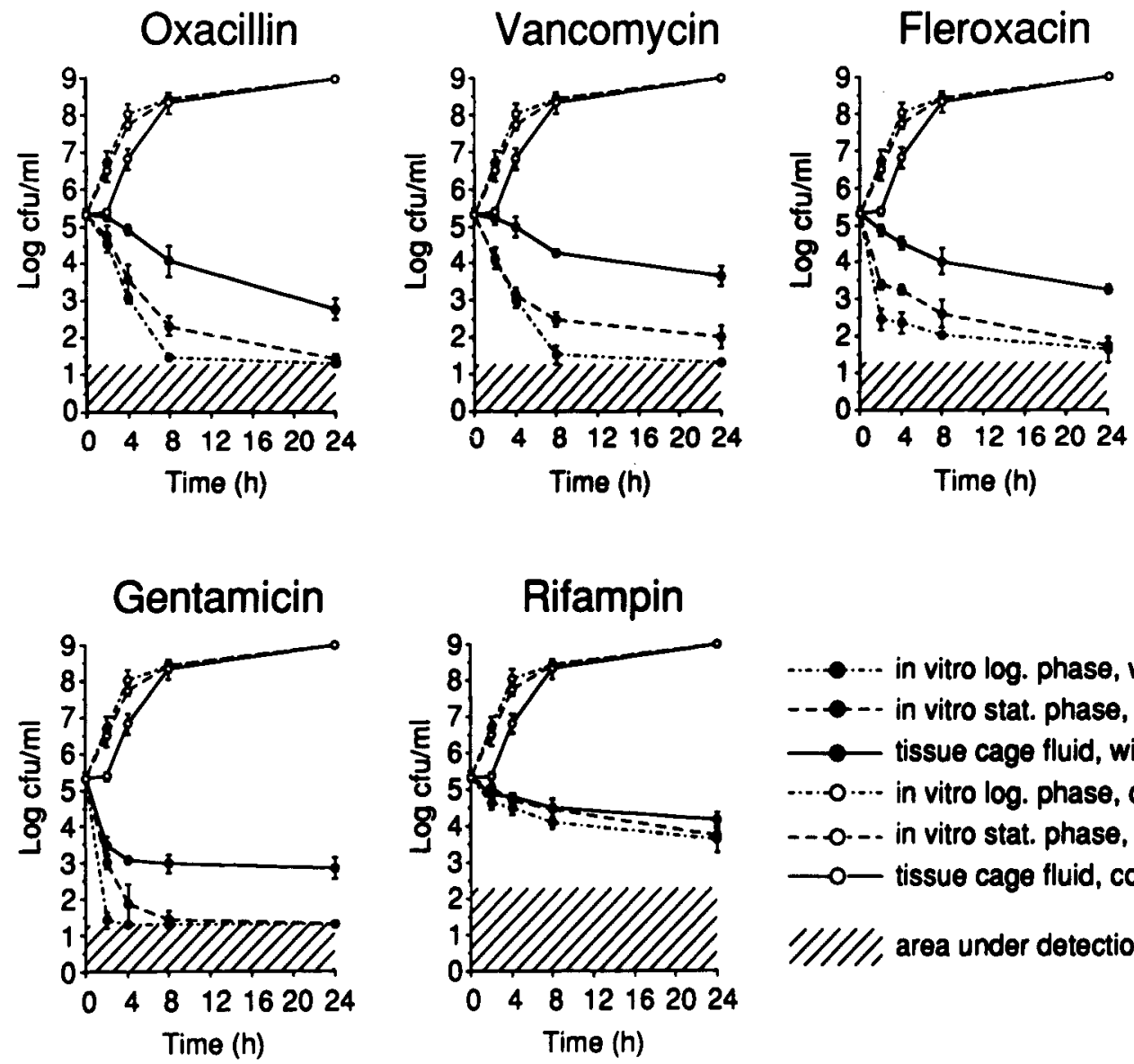

....... in vitro log. phase, with antibiotic

- - - - in vitro stat. phase, with antibiotic

$\longrightarrow$ tissue cage fluid, with antibiotic

........ in vitro log. phase, control

- - - . . in vitro stat. phase, control

$\longrightarrow$ - tissue cage fluid, control

$\mathrm{H} / \mathrm{/} / \mathrm{\text {, }}$ area under detection limit

Figure 1. Killing kinetic studies on Staphylococcus aureus 120 with five antibiotics: oxacillin $(4 \mu \mathrm{g} / \mathrm{ml})$, vancomycin, fleroxacin, gentami$\operatorname{cin}(8 \mu \mathrm{g} / \mathrm{ml}$ each), and rifampin $(2 \mu \mathrm{g} / \mathrm{ml})$. Bacteria grown in vitro to logarithmic and stationary phases were tested as were those recovered from tissue cage fluid. Mean and SD for three experiments for each condition are shown. Inocula at time 0 were standardized to mean inoculum value of all experiments $\left(5.32 \log _{10} \mathrm{cfu} / \mathrm{ml}\right.$; SD, 0.17; range, 5.05-5.52). 
tion or to a particular environment (phenotypic tolerance) has been recognized since the early use of penicillin. In foreign body infections several determinants of phenotypic tolerance are likely to be met. Slow growth is the most classic condition that leads to a decreased susceptibility of bacteria to antibiotics in fluids [11] and on surfaces [12]. It is thought likely that bacteria responsible for infections with prosthetic devices have low metabolic activity. In our experiments, there was a 2-h lag time before the number of cage fluid bacteria increased when bacteria were incubated in MHB without antibiotic; this suggests possible dormancy that differs from the mere stationary phase of an overnight culture. When these bacteria were exposed to antibiotics in a growing phase, after being in MHB for $4 \mathrm{~h}$, their susceptibility to drugs was restored. Nutrient limitation [13] may be implicated in the genesis of resistance to killing in vivo.

A role for the biofilm (aggregates of microorganisms and gross extracellular material) as a barrier against the penetration of antimicrobial agents has been suggested [14]. It appears this is not the unique component that determines the resistance of bacteria associated with foreign body infections to killing, since in our model, resistance was observed for organisms in tissue cage fluid and for bacteria detached from coverslips after disruption of the biofilm. The coating of bacteria by matrix proteins, such as fibronectin and fibrinogen, could also have some importance in vivo; however, incubation of batch culture bacteria in fibronectin in vitro did not alter their susceptibility to killing.

Independent of these conditions, it is possible that surface growth per se is in part responsible for tolerance due to the changes it induces in the ultrastructure of bacteria [15].

In conclusion, $S$. aureus recovered from an experimental subcutaneous tissue cage infection show a marked resistance to the killing effect of antimicrobial agents acting at different bacterial sites. This phenomenon is likely to contribute to the frequent failure of antibiotic therapy of infected implanted devices. A systematic and detailed study of the pathophysiology of bacteria associated with foreign body infections in vitro and in vivo should allow better understanding of the mechanisms of this complex and important clinical problem.

\section{Acknowledgment}

We thank Manuela Bento and Ivana Ratti for excellent technical assistance and Pierre Vaudaux and Jean-Claude Pechere for helpful suggestions.

\section{References}

1. Evans RC, Holmes CJ. Effect of vancomycin hydrochloride on Staphylococcus epidermidis biofilm associated with silicone elastomer. Antimicrob Agents Chemother 1987;31:889-94.

2. Gristina AG, Hobgood CD, Webb LX, Myrvik QN. Adhesive colonization of biomaterials and antibiotic resistance. Biomaterials 1987; 8:423-6.

3. Nickel JC, Ruseska I, Wright JB, Costerton JW. Tobramycin resistance of Pseudomonas aeruginosa cells growing as a biofilm on urinary catheter material. Antimicrob Agents Chemother 1985;27:619-24.

4. Lucet JC, Herrmann M, Rohner P, Auckenthaler R, Waldvogel FA, Lew DP. Treatment of experimental foreign body infection caused by methicillin-resistant Staphylococcus aureus. Antimicrob Agents Chemother 1990;34:2312-7.

5. National Committee for Clinical Laboratory Standards. Methods for determining bactericidal activity of antimicrobial agents. Document M26-P. Villanova, PA: NCCLS, 1987.

6. Woolfrey BF, Lally RT, Ederer MN. Evaluation of oxacillin tolerance in Staphylococcus aureus by a novel method. Antimicrob Agents Chemother 1985;28:381-8.

7. Woolfrey BR, Gresser-Burns ME, Lally RT. Effect of temperature on inoculum as a potential source of error in agar dilution plate count bactericidal measurements. Antimicrob Agents Chemother 1988;32: 513-7.

8. Courvalin P, Goldstein F, Philippon A, Sirot J. Détermination de la concentration minimale bactéricide en milieu solide. In: Courvalin $P$, Goldstein F, Philippon A, Sirot J, eds. L'antibiogramme. Paris: MPCVIDEOM, 1985:195-8.

9. Fernandes CJ, Stevens DA, Groot Obbink DJ, Ackerman VP. A replicator method for the combined determination of minimum inhibitory concentration and minimum bactericidal concentration. J Antimicrob Chemother 1985;15:53-60.

10. Taylor PC, Schoenknecht FD, Sherris JC, Linner EC. Determination of minimum bactericidal concentrations of oxacillin for Staphylococcus aureus: influence and significance of technical factors. Antimicrob Agents Chemother 1983;23:142-50.

11. Cozens RM, Tuomanen E, Tosch W, Zak O, Suter J, Tomasz A. Evaluation of the bactericidal activity of $\beta$-lactam antibiotics on slowly growing bacteria cultured in a chemostat. Antimicrob Agents Chemother 1986;29:797-802.

12. Evans DJ, Brown MRW, Allison DG, Gilbert P. Susceptibility of bacterial biofilm to tobramycin: role of specific growth rate and phase in the division cycle. J Antimicrob Chemother 1990;25:585-91.

13. Brown MRW, Williams P. Influence of substrate limitation and growth phase on sensitivity to antimicrobial agents. J Antimicrob Chemother 1985;15(suppl A):7-14.

14. Costerton JW, Cheng KJ, Geesey GG, et al. Bacterial biofilms in nature and disease. Annu Rev Microbiol 1987;41:435-64.

15. Lorian V, Zak O, Suter J, Bruecher C. Staphylococci, in vitro and in vivo. Diagn Microbiol Infect Dis 1985;3:433-44. 